\title{
Synthesis, Spectral Characterization, and Biological Evaluation of Transition Metal Complexes of Bidentate $N, 0$ Donor Schiff Bases
}

\author{
Sajjad Hussain Sumrra, ${ }^{1}$ Muhammad Ibrahim, ${ }^{2}$ Sabahat Ambreen, ${ }^{3}$ \\ Muhammad Imran, ${ }^{4}$ Muhammad Danish, ${ }^{1}$ and Fouzia Sultana Rehmani ${ }^{3}$ \\ ${ }^{1}$ Department of Chemistry, Institute of Chemical and Biological Sciences, University of Gujrat, Gujrat 50700, Pakistan \\ ${ }^{2}$ Department of Applied Chemistry, Government College University, Faisalabad 38000, Pakistan \\ ${ }^{3}$ Department of Chemistry, University of Karachi, Karachi 75270, Pakistan \\ ${ }^{4}$ Department of Chemistry, Government Emerson College, Multan 60700, Pakistan
}

Correspondence should be addressed to Fouzia Sultana Rehmani; fsrehmani@uok.edu.pk

Received 28 May 2014; Revised 7 July 2014; Accepted 9 July 2014; Published 23 July 2014

Academic Editor: Konstantinos Tsipis

Copyright (c) 2014 Sajjad Hussain Sumrra et al. This is an open access article distributed under the Creative Commons Attribution License, which permits unrestricted use, distribution, and reproduction in any medium, provided the original work is properly cited.

\begin{abstract}
New series of three bidentate $\mathrm{N}$, O donor type Schiff bases $\left(\mathbf{L}^{1}\right)-\left(\mathbf{L}^{3}\right)$ were prepared by using ethylene-1,2-diamine with 5-methyl furfural, 2-anisaldehyde, and 2-hydroxybenzaldehyde in an equimolar ratio. These ligands were further complexed with Co(II), $\mathrm{Cu}(\mathrm{II}), \mathrm{Ni}(\mathrm{II})$, and $\mathrm{Zn}$ (II) metals to produce their new metal complexes having an octahedral geometry. These compounds were characterized on the basis of their physical, spectral, and analytical data. Elemental analysis and spectral data of the uncomplexed ligands and their metal(II) complexes were found to be in good agreement with their structures, indicating high purity of all the compounds. All ligands and their metal complexes were screened for antimicrobial activity. The results of antimicrobial activity indicated that metal complexes have significantly higher activity than corresponding ligands. This higher activity might be due to chelation process which reduces the polarity of metal ion by coordinating with ligands.
\end{abstract}

\section{Introduction}

Schiff bases played an important role as ligands even a century after their discovery in coordination chemistry [1]. Schiff bases are derived from the condensation reaction of aromatic/aliphatic aldehydes and amines. They are an important class of organic ligands being extensively studied. Schiff base complexes of transition metals are still relevant to be of great interest in inorganic chemistry, although this topic has been extensively studied [2-4]. The chelating ability and biological applications of metal complexes have attracted remarkable attention [5]. Metal complexes having N, O donor atoms are very important because of their significant biological properties such as antibacterial [6,7], antifungal [8], anticancer [9], and herbicidal [10] activity. In view of the significant structural and biological applications of ethylenediamine compounds, we wish to report the synthesis of a new class of
Schiff bases $\left(\mathbf{L}^{1}\right)-\left(\mathbf{L}^{3}\right)$, derived from the reaction of ethylene1,2-diamine with 5-methyl furfural, 2-anisaldehyde, and 2hydroxybenzaldehyde, respectively, and their $\mathrm{Co}(\mathrm{II}), \mathrm{Cu}(\mathrm{II})$, $\mathrm{Ni}(\mathrm{II})$, and $\mathrm{Zn}(\mathrm{II})$ metal complexes (1)-(12) (Scheme 2). The compounds were characterized on the basis of physical properties, elemental analysis, infrared and UV-visible spectra, and antimicrobial activities. The Schiff bases and their metal chelates were screened for antibacterial activity against six bacterial strains: Escherichia coli, Streptococcus faecalis, Pseudomonas aeruginosa, Klebsiella pneumoniae, Staphylococcus aureus, and Bacillus subtilis, and also screened for antifungal activity against following six fungal strains: Trichophyton mentogrophytes, Epidermophyton floccosum, Aspergillus niger, Microsporum canis, Fusarium culmorum, and Trichophyton schoenleinii. The Schiff bases showed increased antibacterial activity against certain strains and their activities were enhanced on chelation (see Figures 1 and 2). 


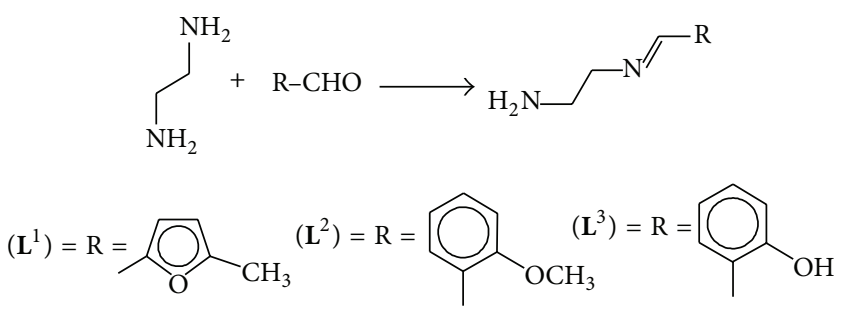

SCHEME 1

\section{Experimental}

2.1. Materials and Methods. Chemicals used were of analytical grade and purchased from commercial sources Sigma Aldrich and were used without further purification. All ligand synthesis reactions were carried out in solvents that were purified and dried before use, using standard literature methods. The redistilled and deionized water was used in all experiments. Gallenkamp apparatus was used to determine melting points of synthesized ligands and decomposition temperature of the metal complexes. Infrared spectra of solids (in a $\mathrm{KBr}$ matrix) were recorded in the $3700-370 \mathrm{~cm}^{-1}$ region on a Nicolet FT-IR Impact 400D infrared spectrometer. ${ }^{1} \mathrm{H}$ and ${ }^{13} \mathrm{CNMR}$ spectra were run on a Bruker Advance $300 \mathrm{MHz}$ instrument. Mass spectrometry work was carried out by Ms. B. Woods N.U.I. Maynooth using an Agilent Technologies 6210 Time-of-Flight LC/MS. UV spectra were obtained on a Hitachi UV-3200 spectrophotometer. Microanalysis ( $\mathrm{C}, \mathrm{H}$, and $\mathrm{N} \%$ ) of the synthesized compounds was carried out using a CHN Analyzer on Perkin Elmer 2400 series II. Molar conductances of the transition metal complexes were measured in 0.01 M in DMF solution using an Inolab Cond 720 Conductivity Bridge at room temperature. A Stanton SM12/S Gouy balance was used to measure the magnetic susceptibility of the metal complexes at room temperature by using mercury acetate as a standard.

2.2. Chemistry of Synthesis of Ligands. Different aldehydes such as 5-methyl furfural, 2-anisaldehyde, and 2-hydroxybenzaldehyde in methanol $(20 \mathrm{~mL})$ were added to a refluxed solution of ethylene-1,2-diamine in same solvent in an equimolar ratio for 10 minutes followed by $2-3$ drops of acetic acid. Then the reaction mixture was refluxed for $6 \mathrm{~h}$ by monitoring through TLC. When the reaction was completed, it was cooled to room temperature, filtered, and volume reduced to about one-third using rotary evaporator. The solid product thus obtained was filtered, washed with methanol, and dried. It was recrystallized in hot methanol/ether $(2: 1)$. The ligands $\left(\mathbf{L}^{\mathbf{1}}\right)-\left(\mathbf{L}^{3}\right)$ were prepared by following the above mentioned method.

2.2.1. N-[(E)-(5-Methylfuran-2-yl)methylidene]ethane-1,2-diamine $\left(\boldsymbol{L}^{1}\right)$. Yield $(1.12 \mathrm{~g}, 73 \%), \mathrm{mp} 175^{\circ} \mathrm{C}$; color reddish brown. ${ }^{1} \mathrm{H}$ NMR (ppm d 6 -DMSO) $2.35\left(\mathrm{~s}, \mathrm{CH}_{3}\right), 3.05$ (s, 2H), 3.68 (s, $2 \mathrm{H}), 4.85\left(\mathrm{~s}, \mathrm{NH}_{2}\right), 6.34(\mathrm{~d}, 2 \mathrm{H}), 6.68(\mathrm{~d}, 2 \mathrm{H}), 7.18(\mathrm{~s}, \mathrm{HC}=\mathrm{N})$; ${ }^{13}$ C NMR: (ppm d 6 -DMSO): 13.5, 43.0, 55.8, 107.2, 116.6, 146.4, 153.3, 162.6; IR $\left(\mathrm{KBr}, \mathrm{cm}^{-1}\right): 3250\left(\mathrm{NH}_{2}\right), 1632(\mathrm{HC}=\mathrm{N}), 1575$,

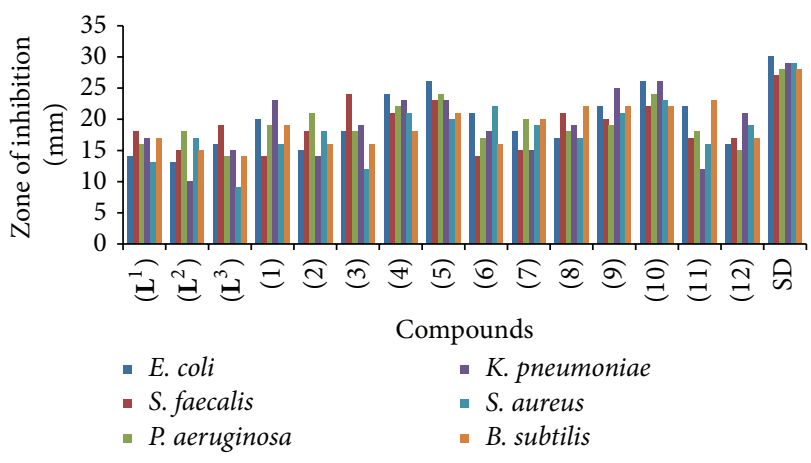

FIGURE 1: Comparison of antibacterial activity of Schiff bases versus metal(II) complexes.

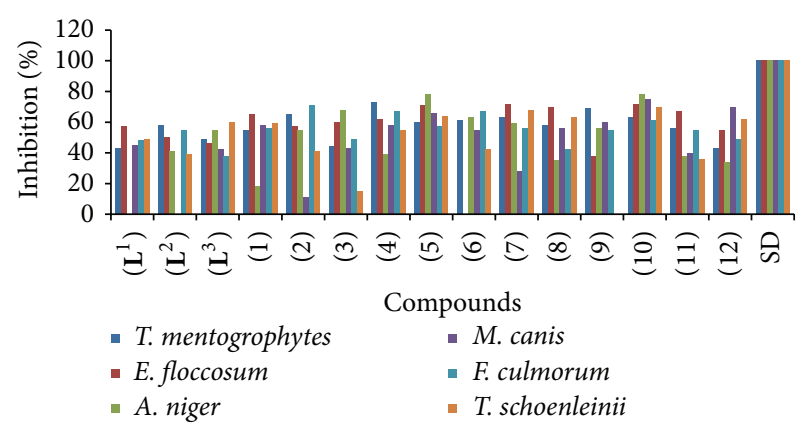

Figure 2: Comparison of antifungal activity of Schiff bases versus metal(II) complexes.

1545 (C=C), 1090 (C-O); Mass Spectrum (ESI) $[\mathrm{M}]^{+}=152.19$. Anal. calcd. for $\mathrm{C}_{8} \mathrm{H}_{12} \mathrm{~N}_{2} \mathrm{O}$ (152.19): C, 63.13; H, 7.95; N, 18.41. Found: C, 63.08; H, 7.93; N, 18.37.

2.2.2. N-[(E)-(2-Methoxyphenyl)methylidene]ethane-1,2-diamine $\left(\boldsymbol{L}^{2}\right)$. Yield $(1.21 \mathrm{~g}, 67 \%)$; mp $142^{\circ} \mathrm{C}$; color dark brown. ${ }^{1} \mathrm{H}$ NMR (ppm d 6 -DMSO): $2.95\left(\mathrm{~s}, \mathrm{OCH}_{3}\right), 3.15$ (s, 2H), 3.85 (s, $2 \mathrm{H}), 4.87\left(\mathrm{~s}, \mathrm{NH}_{2}\right), 6.87(\mathrm{t}, 1 \mathrm{H}), 6.95(\mathrm{~d}, 1 \mathrm{H}), 7.32(\mathrm{t}, 1 \mathrm{H}), 7.59$ $(\mathrm{d}, 1 \mathrm{H}), 8.78(\mathrm{~s}, \mathrm{HC}=\mathrm{N}) ;{ }^{13} \mathrm{C}$ NMR: (ppm d 6 -DMSO): 44.2, 53.6, 56.3, 114.7, 122.9, 123.7, 129.6, 134.5, 160.5, 162.3; IR ( $\mathrm{KBr}$, $\left.\mathrm{cm}^{-1}\right): 3255\left(\mathrm{NH}_{2}\right), 2920\left(\mathrm{OCH}_{3}\right), 1635(\mathrm{HC}=\mathrm{N}), 1577,1543$ $(\mathrm{C}=\mathrm{C})$; Mass Spectrum (ESI): $[\mathrm{M}]^{+}=178.23$. Anal. calcd. for $\mathrm{C}_{10} \mathrm{H}_{14} \mathrm{~N}_{2} \mathrm{O}$ (178.23): C, 67.39; H, 7.92; N, 15.72. Found: C, $67.33 ; \mathrm{H}, 7.88 ; \mathrm{N}, 15.69$.

2.2.3. 2-\{(E)-[(2-Aminoethyl)imino $]$ methyl $\}$ phenol $\left(\boldsymbol{L}^{3}\right)$. Yield (1.20 g, 73\%); mp: $155^{\circ} \mathrm{C}$, color (yellow). ${ }^{1} \mathrm{H}$ NMR (ppm d $6^{-}$ DMSO): 3.40 (s, 2H), 3.98 (s, 2H), 4.89 (s, $\left.\mathrm{NH}_{2}\right), 6.93(\mathrm{t}, 1 \mathrm{H})$, $7.11(\mathrm{~d}, 1 \mathrm{H}), 7.43(\mathrm{t}, 1 \mathrm{H}), 7.72(\mathrm{~d}, 1 \mathrm{H}), 8.85(\mathrm{~s}, \mathrm{HC}=\mathrm{N}), 9.97$ (s, OH); ${ }^{13} \mathrm{C}$ NMR (ppm d 6 -DMSO): 44.8, 52.9, 118.4, 119.5, 122.2, 131.5, 133.1, 159.2, 162.3; IR $\left(\mathrm{KBr}, \mathrm{cm}^{-1}\right): 3385(\mathrm{OH}), 3253$ $\left(\mathrm{NH}_{2}\right), 1638(\mathrm{HC}=\mathrm{N})$; Mass Spectrum (ESI): $[\mathrm{M}]^{+}=164.20$. Anal. calcd. for $\mathrm{C}_{9} \mathrm{H}_{12} \mathrm{~N}_{2} \mathrm{O}$ (164.20): C, 65.83; H, 7.37; N, 17.06. Found: C, 65.77; H, 7.32; N, 17.02. 

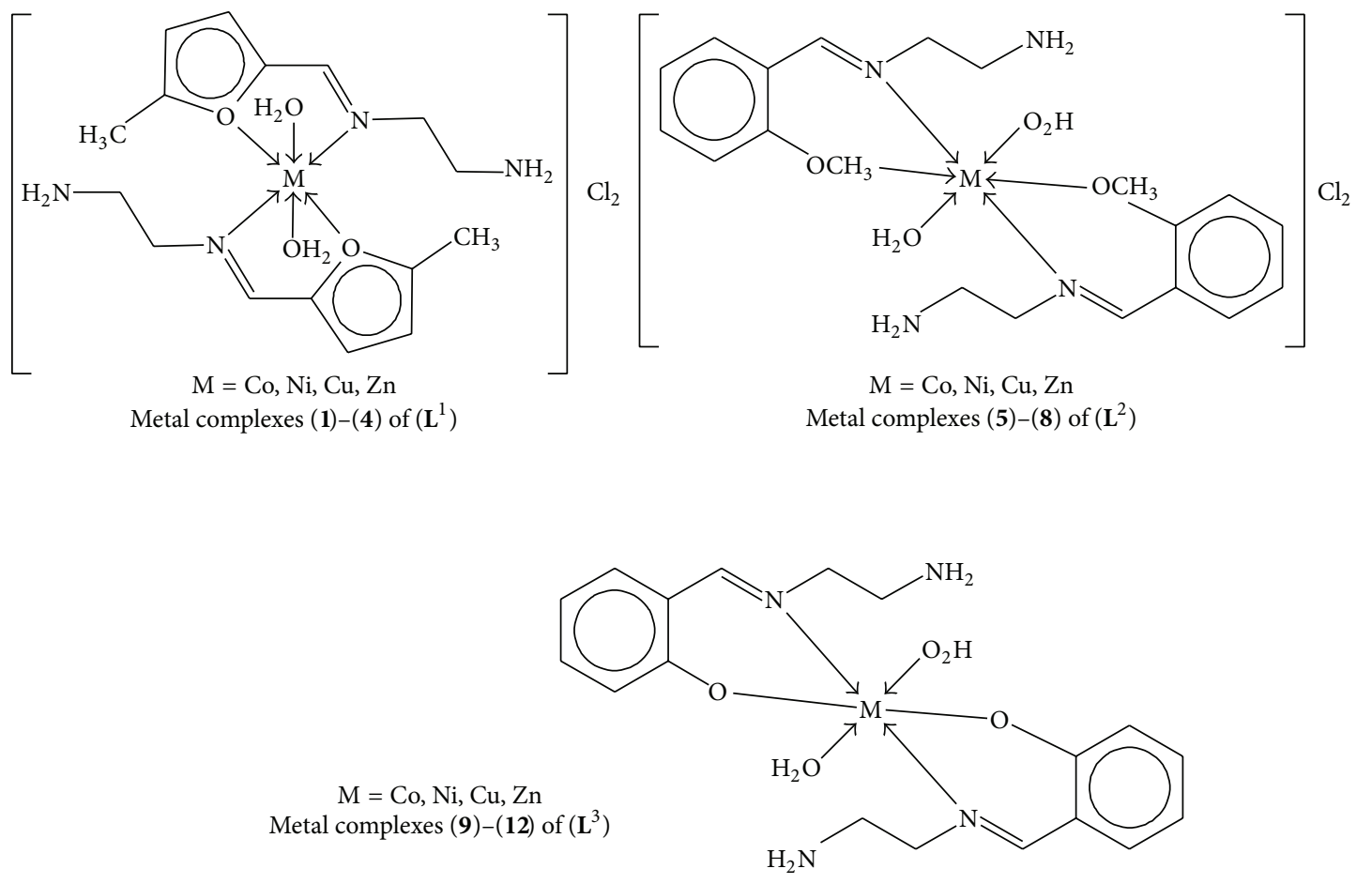

SCHEME 2

2.3. Chemistry of Synthesis of the Transition Metal(II) Complexes. All complexes were prepared according to the following procedure: to a hot magnetically refluxed methanol solution $(30 \mathrm{~mL})$ of the respective Schiff base ligand $(10 \mathrm{mmol})$, a methanol solution $(20 \mathrm{~mL})$ of respective metal(II) salt chloride $n \mathrm{H}_{2} \mathrm{O}(5 \mathrm{mmol})$ was added $(n=0,2$ or 6$)$. The mixture was refluxed for $3 \mathrm{~h}$, during which a precipitated product was formed. It was then cooled to room temperature, filtered, and washed with methanol and finally with diethyl ether. The precipitated product thus obtained was dried and recrystallized in a mixture of hot aqueous methanol $(1: 2)$ to obtain TLC pure product.

2.3.1. Co(II) Metal Complex of $\left(\mathbf{L}^{\mathbf{1}}\right)$ (1). Yield (1.45 g, 62\%), mp 232-234 ${ }^{\circ} \mathrm{C}$, IR (KBr) $3465\left(\mathrm{H}_{2} \mathrm{O}\right), 1617(\mathrm{HC}=\mathrm{N}), 1074(\mathrm{C}-\mathrm{O})$, $525(\mathrm{M}-\mathrm{N}), 457$ (M-O); UV (DMSO) $\lambda_{\max }\left(\mathrm{cm}^{-1}\right) 8515,17511$ and 29982; conductance $\left(\Omega^{-1} \mathrm{~cm}^{2} \mathrm{~mol}^{-1}\right)$ 98.5; B.M. $\left(\mu_{\mathrm{eff}}\right)$ : 4.68. Anal. calcd. for $\mathrm{C}_{16} \mathrm{H}_{28} \mathrm{~N}_{4} \mathrm{O}_{4} \mathrm{CoCl}_{2}$ (470.35); C, 40.78; H, 5.95; N, 11.91; Co, 12.53. Found: C, 40.71; H, 5.91; N, 11.88; Co, 12.48

2.3.2. Ni(II) Metal Complex of ( $\left.\boldsymbol{L}^{\mathbf{1}}\right)$ (2). Yield (1.50 g, 64\%), $\mathrm{mp} 225-227^{\circ} \mathrm{C}$; IR $(\mathrm{KBr}): 3474\left(\mathrm{H}_{2} \mathrm{O}\right), 1619(\mathrm{HC}=\mathrm{N}), 1077(\mathrm{C}-$ O), $527(\mathrm{M}-\mathrm{N}), 454(\mathrm{M}-\mathrm{O})$; UV (DMSO) $\lambda_{\max }\left(\mathrm{cm}^{-1}\right): 8623$, 17620, 25890 and 29895; conductance $\left(\Omega^{-1} \mathrm{~cm}^{2} \mathrm{~mol}^{-1}\right): 97.4$; B.M. $\left(\mu_{\text {eff }}\right)$ : 3.42. Anal. calcd. for $\mathrm{C}_{16} \mathrm{H}_{28} \mathrm{~N}_{4} \mathrm{O}_{4} \mathrm{NiCl}_{2}$ (470.11); C, 40.84; H, 5.95; N, 11.91, Ni, 12.48. Found: C, 40.77; H, 5.93; $\mathrm{N}, 11.86 ; \mathrm{Ni}, 12.45$.

2.3.3. Cu(II) Metal Complex of ( $\left.\boldsymbol{L}^{1}\right)$ (3). Yield (1.37g, 58\%);

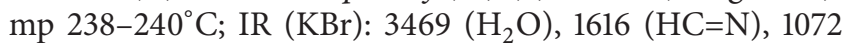
(C-O), $523(\mathrm{M}-\mathrm{N}), 454(\mathrm{M}-\mathrm{O})$; UV (DMSO) $\lambda_{\max }\left(\mathrm{cm}^{-1}\right)$ :
8515, 17511 and 29982; conductance $\left(\Omega^{-1} \mathrm{~cm}^{2} \mathrm{~mol}^{-1}\right)$ : 98.9; B.M. $\left(\mu_{\text {eff }}\right)$ : 1.97. Anal. calcd. for $\mathrm{C}_{16} \mathrm{H}_{28} \mathrm{~N}_{4} \mathrm{O}_{4} \mathrm{CuCl}_{2}$ (474.96); C, 40.42; H, 5.89; N, 11.79; Cu, 13.38. Found: C, 40.34; H, 5.83; $\mathrm{N}, 11.72 ; \mathrm{Cu}, 13.31$.

2.3.4. Zn(II) Metal Complex of ( $\left.\boldsymbol{L}^{1}\right)$ (4). Yield (1.51 g, 63\%); mp 216-218 ${ }^{\circ} \mathrm{C}$; ${ }^{1} \mathrm{H}$ NMR: (ppm d ${ }_{6}$-DMSO): $2.46\left(\mathrm{~s}, \mathrm{CH}_{3}\right)$, 3.15 (s, 2H), 3.83 (s, 2H), $4.98\left(\mathrm{~s}, \mathrm{NH}_{2}\right), 6.48(\mathrm{~d}, 2 \mathrm{H}), 6.80$ $(\mathrm{d}, 2 \mathrm{H}), 7.48(\mathrm{~s}, \mathrm{HC}=\mathrm{N}), 10.5\left(\mathrm{~s}, 4 \mathrm{H}, \mathrm{H}_{2} \mathrm{O}\right) ;{ }^{13} \mathrm{C} \mathrm{NMR}(\mathrm{ppm}$ $\mathrm{d}_{6}$-DMSO): 13.9, 43.4, 56.4, 107.9, 117.7, 147.6, 154.6, 163.8; IR $(\mathrm{KBr}): 3480\left(\mathrm{H}_{2} \mathrm{O}\right), 1612(\mathrm{HC}=\mathrm{N}), 1077(\mathrm{C}-\mathrm{O}), 529(\mathrm{M}-\mathrm{N})$, 459 (M-O); UV (DMSO) $\lambda_{\max }\left(\mathrm{cm}^{-1}\right): 28382$; conductance $\left(\Omega^{-1} \mathrm{~cm}^{2} \mathrm{~mol}^{-1}\right)$ : 97.5; B.M. $\left(\mu_{\mathrm{eff}}\right)$ : diamagnetic. Anal. calcd. for $\mathrm{C}_{16} \mathrm{H}_{28} \mathrm{~N}_{4} \mathrm{O}_{4} \mathrm{ZnCl}_{2}$ (476.82); C, 40.26; H, 5.87; N, 11.74; Zn, 13.71. Found: C, 40.18; H, 5.83; N, 11.69; Zn, 13.66.

2.3.5. Co(II) Metal Complex of $\left(\mathbf{L}^{2}\right)$ (5). Yield (1.55 g, 59\%), $\mathrm{mp} 248-251^{\circ} \mathrm{C}$, IR (KBr) $3465\left(\mathrm{H}_{2} \mathrm{O}\right), 1621(\mathrm{HC}=\mathrm{N}), 1380(\mathrm{C}-$ $\mathrm{O}), 532(\mathrm{M}-\mathrm{N}), 465(\mathrm{M}-\mathrm{O})$; UV (DMSO) $\lambda_{\max }\left(\mathrm{cm}^{-1}\right) 8690$, 17823 and 29622; conductance $\left(\Omega^{-1} \mathrm{~cm}^{2} \mathrm{~mol}^{-1}\right)$ 97.7; B.M. $\left(\mu_{\text {eff }}\right)$ : 4.55. Anal. calcd. for $\mathrm{C}_{20} \mathrm{H}_{32} \mathrm{~N}_{4} \mathrm{O}_{4} \mathrm{CoCl}_{2}$ (522.42); C, 45.94; H, 6.12; N, 10.71; Co, 11.28. Found: C, 45.88; H, 6.08; N, 11.69; Co, 11.28.

2.3.6. $\mathrm{Ni}(\mathrm{II})$ Metal Complex of $\left(\boldsymbol{L}^{2}\right)$ (6). Yield (1.58 g, 61\%), mp 229-231 ${ }^{\circ} \mathrm{C}$; IR (KBr): $3474\left(\mathrm{H}_{2} \mathrm{O}\right), 1617(\mathrm{HC}=\mathrm{N}), 1383(\mathrm{C}-$ $\mathrm{O}), 520(\mathrm{M}-\mathrm{N}), 447(\mathrm{M}-\mathrm{O})$; UV (DMSO) $\lambda_{\max }\left(\mathrm{cm}^{-1}\right): 8710$, 17850, 25715 and 29675; conductance $\left(\Omega^{-1} \mathrm{~cm}^{2} \mathrm{~mol}^{-1}\right): 98.2$; B.M. $\left(\mu_{\text {eff }}\right)$ : 3.55. Anal. calcd. for $\mathrm{C}_{20} \mathrm{H}_{32} \mathrm{~N}_{4} \mathrm{O}_{4} \mathrm{NiCl}_{2}$ (522.18); C, 45.99; H, 6.12; N, 10.71, Ni, 11.23. Found: C, 45.92; H, 6.09; N, 11.66; Ni, 11.28. 
TABLE 1: Antibacterial bioassay of ligands and their metal(II) complexes (zone of inhibition in mm).

\begin{tabular}{|c|c|c|c|c|c|c|c|}
\hline Compounds & (a) & (b) & (c) & (d) & (e) & (f) & SA \\
\hline$\left(\mathrm{L}^{1}\right)$ & 14 & 18 & 16 & 17 & 13 & 17 & 1.94 \\
\hline$\left(\mathbf{L}^{2}\right)$ & 13 & 15 & 18 & 10 & 17 & 15 & 2.88 \\
\hline$\left(\mathbf{L}^{3}\right)$ & 16 & 19 & 14 & 15 & 09 & 14 & 3.27 \\
\hline (1) & 20 & 14 & 19 & 23 & 16 & 19 & 3.15 \\
\hline (2) & 15 & 18 & 21 & 14 & 18 & 16 & 2.53 \\
\hline (3) & 18 & 24 & 18 & 19 & 12 & 16 & 3.92 \\
\hline (4) & 24 & 21 & 22 & 23 & 21 & 18 & 2.07 \\
\hline (5) & 26 & 23 & 24 & 23 & 20 & 21 & 2.14 \\
\hline (6) & 21 & 14 & 17 & 18 & 22 & 16 & 3.03 \\
\hline (7) & 18 & 15 & 20 & 15 & 19 & 20 & 2.32 \\
\hline (8) & 17 & 21 & 18 & 19 & 17 & 22 & 2.10 \\
\hline (9) & 22 & 20 & 19 & 25 & 21 & 22 & 2.07 \\
\hline (10) & 26 & 22 & 24 & 26 & 23 & 22 & 1.83 \\
\hline (11) & 22 & 17 & 18 & 12 & 16 & 23 & 4.05 \\
\hline (12) & 16 & 17 & 15 & 21 & 19 & 17 & 2.07 \\
\hline SD & 30 & 27 & 28 & 29 & 29 & 28 & 1.05 \\
\hline
\end{tabular}

(a) E. coli; (b) S. faecalis; (c) P. aeruginosa; (d) K. pneumoniae; (e) S. aureus; (f) B. subtilis; SD: standard drug; weaker = 0-10 mm, moderate = 11-15 mm, above $15 \mathrm{~mm}=$ significant, and $\mathrm{SA}=$ statistical analysis.

2.3.7. Cu(II) Metal Complex of $\left(\mathbf{L}^{2}\right)$ (7). Yield (1.71g, 65\%); mp 252-255 C; IR (KBr): $3469\left(\mathrm{H}_{2} \mathrm{O}\right), 1615(\mathrm{HC}=\mathrm{N}), 1377$ (C-O), $535(\mathrm{M}-\mathrm{N}), 459$ (M-O); UV (DMSO) $\lambda_{\max }\left(\mathrm{cm}^{-1}\right)$ : 8705, 17215 and 29528; conductance $\left(\Omega^{-1} \mathrm{~cm}^{2} \mathrm{~mol}^{-1}\right)$ : 97.7; B.M. $\left(\mu_{\text {eff }}\right): 1.92$. Anal. calcd. for $\mathrm{C}_{20} \mathrm{H}_{32} \mathrm{~N}_{4} \mathrm{O}_{4} \mathrm{CuCl}_{2}(527.04)$; C, 45.53; H, 6.07; N, 10.62; Cu, 12.05. Found: C, 45.48; H, 6.01; $\mathrm{N}, 10.69 ; \mathrm{Cu}, 12.01$.

2.3.8. Zn(II) Metal Complex of $\left(\boldsymbol{L}^{2}\right)$ (8). Yield (1.74 g, 66\%); mp 259-262 ${ }^{\circ}$; ${ }^{1} \mathrm{H}$ NMR: (ppm d 6 -DMSO): $3.03\left(\mathrm{~s}, \mathrm{OCH}_{3}\right.$ ), $3.22(\mathrm{~s}, 2 \mathrm{H}), 3.93(\mathrm{~s}, 2 \mathrm{H}), 4.96\left(\mathrm{~s}, \mathrm{NH}_{2}\right), 6.95(\mathrm{t}, 1 \mathrm{H})$, $7.02(\mathrm{~d}, 1 \mathrm{H}), 7.42(\mathrm{t}, 1 \mathrm{H}), 7.65(\mathrm{~d}, 1 \mathrm{H}), 8.93(\mathrm{~s}, \mathrm{HC}=\mathrm{N})$, 10.5 (s, 4H, $\mathrm{H}_{2} \mathrm{O}$ ); ${ }^{13} \mathrm{C} \mathrm{NMR}$ (ppm d 6 -DMSO): 44.6, 53.9, $56.8,115.3,123.7,124.6,130.4,134.9,160.8,163.5$; IR (KBr): $3480\left(\mathrm{H}_{2} \mathrm{O}\right), 1612(\mathrm{HC}=\mathrm{N}), 1382(\mathrm{C}-\mathrm{O}), 527(\mathrm{M}-\mathrm{N}), 454$ (M-O); UV (DMSO) $\lambda_{\max }\left(\mathrm{cm}^{-1}\right): 28538$; conductance $\left(\Omega^{-1} \mathrm{~cm}^{2} \mathrm{~mol}^{-1}\right)$ : 93.5; B.M. $\left(\mu_{\mathrm{eff}}\right)$ : diamagnetic. Anal. calcd. for $\mathrm{C}_{20} \mathrm{H}_{32} \mathrm{~N}_{4} \mathrm{O}_{4} \mathrm{ZnCl}_{2}$ (528.90); C, 45.37; H, 6.05; N, 10.58; Zn, 12.36. Found: C, 45.28; H, 5.99; N, 11.51; Zn, 12.28.

2.3.9. Co(II) Metal Complex of $\left(\mathbf{L}^{3}\right)$ (9). Yield (1.41 g, 67\%), $\mathrm{mp} 224-227^{\circ} \mathrm{C}$, IR (KBr) $3465\left(\mathrm{H}_{2} \mathrm{O}\right), 1623(\mathrm{HC}=\mathrm{N}), 1377(\mathrm{C}-$ $\mathrm{O}), 538(\mathrm{M}-\mathrm{N}), 455(\mathrm{M}-\mathrm{O})$; UV (DMSO) $\lambda_{\text {max }}\left(\mathrm{cm}^{-1}\right) 8587$, 17967 and 29745; conductance $\left(\Omega^{-1} \mathrm{~cm}^{2} \mathrm{~mol}^{-1}\right)$ 15.6; B.M. $\left(\mu_{\text {eff }}\right)$ : 4.32. Anal. calcd. for $\mathrm{C}_{18} \mathrm{H}_{26} \mathrm{~N}_{4} \mathrm{O}_{4} \mathrm{Co}$ (421.36); C, 51.31; H, 6.22; N, 13.30; Co, 13.99. Found: C, 51.22; H, 6.16; N, 13.24; Co, 13.92 .

2.3.10. Ni(II) Metal Complex of $\left(\boldsymbol{L}^{3}\right)$ (10). Yield (1.58 g, 61\%), $\mathrm{mp} 229-231^{\circ} \mathrm{C}$; IR (KBr): $3474\left(\mathrm{H}_{2} \mathrm{O}\right), 1619(\mathrm{HC}=\mathrm{N}), 1381(\mathrm{C}-$ $\mathrm{O}), 535(\mathrm{M}-\mathrm{N}), 441(\mathrm{M}-\mathrm{O})$; UV (DMSO) $\lambda_{\max }\left(\mathrm{cm}^{-1}\right): 8599$, 17645, 25661 and 29717; conductance $\left(\Omega^{-1} \mathrm{~cm}^{2} \mathrm{~mol}^{-1}\right): 14.2$; B.M. $\left(\mu_{\text {eff }}\right)$ : 3.39. Anal. calcd. for $\mathrm{C}_{18} \mathrm{H}_{26} \mathrm{~N}_{4} \mathrm{O}_{4} \mathrm{Ni}$ (421.12); C,
51.34; H, 6.22; N, 13.30, Ni, 13.94. Found: C, 51.26; H, 6.19; N, 13.26; Ni, 13.88 .

2.3.11. Cu(II) Metal Complex of $\left(\boldsymbol{L}^{3}\right)$ (11). Yield (1.34 g, 63\%); mp 235-237 $\mathrm{C}$; IR (KBr): $3469\left(\mathrm{H}_{2} \mathrm{O}\right), 1619(\mathrm{HC}=\mathrm{N}), 1375$ (C-O), $539(\mathrm{M}-\mathrm{N}), 448(\mathrm{M}-\mathrm{O})$; UV (DMSO) $\lambda_{\max }\left(\mathrm{cm}^{-1}\right)$ : 8670, 17371 and 29732; conductance $\left(\Omega^{-1} \mathrm{~cm}^{2} \mathrm{~mol}^{-1}\right): 13.4$; B.M. $\left(\mu_{\text {eff }}\right)$ : 1.93. Anal. calcd. for $\mathrm{C}_{18} \mathrm{H}_{26} \mathrm{~N}_{4} \mathrm{O}_{4} \mathrm{Cu}$ (425.96); C, 50.75; H, 6.15; N, 13.15; Cu, 14.92. Found: C, 50.68; H, 6.11; N, $13.10 ; \mathrm{Cu}, 14.85$.

2.3.12. $\mathrm{Zn}(\mathrm{II})$ Metal Complex of $\left(\boldsymbol{L}^{3}\right)$ (12). Yield (1.51 g, 71\%); mp 239-241 ${ }^{\circ} \mathrm{C} ;{ }^{1} \mathrm{H}$ NMR: (ppm d 6 -DMSO): 3.54 (s, 2H), 4.14 (s, 2H), $4.0\left(\mathrm{~s}, \mathrm{NH}_{2}\right), 7.09$ (t, 1H), $7.34(\mathrm{~d}, 1 \mathrm{H}), 7.55(\mathrm{t}, 1 \mathrm{H}), 7.87$ $(\mathrm{d}, 1 \mathrm{H}) 8.98(\mathrm{~s}, \mathrm{HC}=\mathrm{N}), 10.5\left(\mathrm{~s}, 4 \mathrm{H}, \mathrm{H}_{2} \mathrm{O}\right) ;{ }^{13} \mathrm{C} \mathrm{NMR}\left(\mathrm{ppm} \mathrm{d}_{6}{ }^{-}\right.$ DMSO): 45.2, 53.5, 118.7, 119.7, 122.7, 131.9, 133.5, 159.7, 162.9; IR (KBr): $3480\left(\mathrm{H}_{2} \mathrm{O}\right), 1619(\mathrm{HC}=\mathrm{N}), 1376(\mathrm{C}-\mathrm{O}), 532(\mathrm{M}-\mathrm{N})$, 445 (M-O); UV (DMSO) $\lambda_{\max }\left(\mathrm{cm}^{-1}\right): 28653$; conductance $\left(\Omega^{-1} \mathrm{~cm}^{2} \mathrm{~mol}^{-1}\right)$ : 13.5; B.M. $\left(\mu_{\mathrm{eff}}\right)$ : diamagnetic. Anal. calcd. for $\mathrm{C}_{18} \mathrm{H}_{26} \mathrm{~N}_{4} \mathrm{O}_{4} \mathrm{Zn}$ (427.83); C, 50.53; H, 6.13; N, 13.10; Zn, 15.29. Found: C, 50.45; H, 6.09; N, 13.05; Zn, 15.22 .

\subsection{Biological Activity}

2.4.1. In Vitro Antibacterial Activity. All newly synthesized Schiff bases $\left(\mathbf{L}^{\mathbf{1}}\right)-\left(\mathrm{L}^{3}\right)$ and their transition metal(II) complexes (1)-(12) were screened for their in vitro antibacterial activity against (Escherichia coli, Streptococcus faecalis, Pseudomonas aeruginosa, Klebsiella pneumoniae, Staphylococcus aureus, and Bacillus subtilis) bacterial strains by the agarwell diffusion method [11] and recorded in Table 1. Small portion $(10 \mathrm{~mL})$ of nutrient broth was inoculated with the test organisms and incubated at $37^{\circ} \mathrm{C}$ for $24 \mathrm{~h}$. Using a sterile 
TABle 2: Antifungal bioassay of ligands and their metal(II) complexes (\% inhibition).

\begin{tabular}{|c|c|c|c|c|c|c|c|}
\hline Compounds & (a) & (b) & (c) & (d) & (e) & (f) & SA \\
\hline$\left(\mathbf{L}^{1}\right)$ & 43 & 57 & 00 & 45 & 48 & 49 & 20.33 \\
\hline$\left(\mathbf{L}^{2}\right)$ & 58 & 50 & 41 & 00 & 55 & 39 & 21.21 \\
\hline$\left(\mathbf{L}^{3}\right)$ & 49 & 46 & 55 & 42 & 38 & 60 & 8.16 \\
\hline (1) & 55 & 65 & 18 & 58 & 56 & 59 & 16.94 \\
\hline (2) & 65 & 57 & 55 & 11 & 71 & 41 & 21.64 \\
\hline (3) & 44 & 60 & 68 & 43 & 49 & 15 & 18.22 \\
\hline (4) & 73 & 62 & 39 & 58 & 67 & 55 & 11.71 \\
\hline (5) & 60 & 71 & 78 & 66 & 57 & 74 & 8.16 \\
\hline (6) & 61 & 00 & 63 & 55 & 67 & 42 & 25.07 \\
\hline (7) & 63 & 72 & 59 & 28 & 56 & 68 & 15.65 \\
\hline (8) & 58 & 70 & 35 & 56 & 42 & 63 & 13.13 \\
\hline (9) & 69 & 38 & 56 & 60 & 55 & 00 & 24.84 \\
\hline (10) & 63 & 72 & 78 & 75 & 61 & 70 & 6.68 \\
\hline (11) & 56 & 67 & 38 & 40 & 55 & 36 & 12.48 \\
\hline (12) & 43 & 55 & 34 & 70 & 49 & 62 & 13.01 \\
\hline
\end{tabular}

(a) T. mentogrophytes; (b) E. floccosum; (c) A. niger; (d) M. canis; (e) F.culmorum; (f) T. schoenleinii; weaker $=0-30 \%$, moderate $=31-54 \%, 55-100 \%=$ significant, and $\mathrm{SA}=$ statistical analysis.

pipette, $0.6 \mathrm{~mL}$ of the broth culture of the test organism was added to $60 \mathrm{~mL}$ of molten agar which had been cooled to $45^{\circ} \mathrm{C}$, mixed well, and poured into a sterile petri dish. Duplicate plates of each organism were prepared. The agar was allowed to set and harden and the required numbers of holes were cut using a sterile cork borer ensuring proper distribution of holes on the border and one in the center. Agar plugs were removed. Different cork borers were used for different test organisms. Using a $0.1 \mathrm{~mL}$ pipette, $100 \mu \mathrm{L}$ of the test sample dissolved in an appropriate solvent was poured into appropriately labelled cups. The same concentrations of the standard antibacterial agent (streptomycin in $1 \mathrm{mg} / \mathrm{mL}$ ) and the solvent (as control) were used. The plates were left at room temperature for $2 \mathrm{~h}$ to allow diffusion of the sample and incubated face upwards at $37^{\circ} \mathrm{C}$ for $24 \mathrm{~h}$. The diameter of the zones of inhibition was measured to the nearest $\mathrm{mm}$.

2.4.2. In Vitro Antifungal Activity. Antifungal activities of all compounds were studied against six fungal strains Trichophyton mentogrophytes, Epidermophyton floccosum, Aspergillus niger, Microsporum canis, Fusarium culmorum, and Trichophyton schoenleinii according to recommended procedure [12] and recorded in Table 2. Test sample was dissolved in sterile DMSO to serve as stock solution. Sabouraud dextrose agar was prepared by mixing Sabouraud $4 \%$ glucose agar and agar in distilled water. It was then stirred with a magnetic stirrer to dissolve it and a known amount was dispensed into screw capped test tubes. Test tubes containing media were autoclaved at $121^{\circ} \mathrm{C}$ for $15 \mathrm{~min}$. Tubes were allowed to cool to $50^{\circ} \mathrm{C}$ and the test sample of desired concentrations pipetted from the stock solution into the nonsolidified Sabouraud agar media. Tubes were then allowed to solidify in a slanting position at room temperature. Each tube was inoculated with a $4 \mathrm{~mm}$ diameter piece of inoculum removed from a sevenday-old culture of fungi.
2.4.3. Minimum Inhibitory Concentration (MIC). Compounds containing promising antibacterial activity were selected for minimum inhibitory concentration (MIC) studies [13]. The minimum inhibitory concentration was determined using the disc diffusion technique by preparing discs containing $10,25,50$, and $100 \mu \mathrm{g} \mathrm{mL}^{-1}$ concentrations of the compounds along with standards at the same concentrations.

\section{Results and Discussion}

The condensation of ethylene-1,2-diamine and 5-methyl furfural, 2-anisaldehyde, and 2-hydroxybenzaldehyde in 1:1 molar ratio afforded three Schiff base ligands $\left(\mathbf{L}^{\mathbf{1}}\right)-\left(\mathbf{L}^{3}\right)$ (Scheme 1). These ligands were air and moisture stable compounds. All of them were colored compounds. These were microcrystalline solids which melted at $145-175^{\circ} \mathrm{C}$. All were soluble in DMSO and DMF at room temperature and soluble on heating in methanol and ethanol.

These bidentate ligands reacted readily with $\mathrm{Co}(\mathrm{II})$, $\mathrm{Cu}(\mathrm{II}), \mathrm{Ni}(\mathrm{II})$, and $\mathrm{Zn}(\mathrm{II})$ metals as their chlorides $\left[\mathrm{CoCl}_{2} \cdot 6 \mathrm{H}_{2} \mathrm{O}, \mathrm{NiCl}_{2} \cdot 6 \mathrm{H}_{2} \mathrm{O}, \mathrm{CuCl}_{2} \cdot 2 \mathrm{H}_{2} \mathrm{O}\right.$, and $\left.\mathrm{ZnCl}_{2}\right]$ in methanol to form their metal(II) complexes (Scheme 2). All the synthesized metal(II) complexes were intensely colored except $\mathrm{Zn}$ (II) complexes which were white and all complexes were microcrystalline in nature. The metal(II) complexes decomposed without melting. They were all insoluble in common organic solvents such as ethanol, methanol, dichloromethane, and acetone but soluble in DMSO and DMF.

The spectral data and elemental analysis of the prepared ligands and their metal(II) complexes were in good agreement with their structure, indicating the high purity of all the compounds. The analytical data of the complexes indicated a 1:2 metal : ligand stoichiometry. 
3.1. IR Spectra. These ligands can coordinate through the azomethine- $\mathrm{N}$, furanyl-O, methoxy-O, and oxygen atom from the deprotonation of the phenolic group. Some of the characteristic IR spectral data were reported in experimental part. The ligands $\left(\mathbf{L}^{1}\right)-\left(\mathbf{L}^{3}\right)$ displayed band at $3250-3255 \mathrm{~cm}^{-1}$ resulting from $\mathrm{NH}_{2}$ vibrations [14]. The ligand $\left(\mathbf{L}^{3}\right)$ showed band resulting from $\mathrm{OH}$ vibrations [15] at $3385 \mathrm{~cm}^{-1}$. However, the IR spectra of the ligand $\left(\mathbf{L}^{2}\right)$ demonstrated vibrations at $2920 \mathrm{~cm}^{-1}$ due to $\mathrm{OCH}_{3}$ stretching [16]. The Schiff bases $\left(\mathbf{L}^{1}\right)-\left(\mathbf{L}^{3}\right)$ possessed the characteristic azomethine $(\mathrm{HC}=\mathrm{N})$ stretching [17] at $1632-1638 \mathrm{~cm}^{-1}$, hence giving clue of condensation product. The ligand $\left(\mathrm{L}^{1}\right)$ showed the bands at $1090 \mathrm{~cm}^{-1}$ due to $(\mathrm{C}-\mathrm{O})$ vibrations [18]. The comparison of the IR spectra of the Schiff bases $\left(\mathrm{L}^{1}\right)-\left(\mathrm{L}^{3}\right)$ with their metal(II) complexes (1)-(12) indicated that the Schiff bases were principally coordinated to the metal(II) ions bidentately. The IR bands of azomethine group appearing in Schiff bases complexes shifted to lower frequency $\left(10-15 \mathrm{~cm}^{-1}\right)$ at $1612-$ $1623 \mathrm{~cm}^{-1}$ confirming the coordination of the azomethine nitrogen [19] with the metal(II) atoms. IR bands at 3250$3255 \mathrm{~cm}^{-1}$ resulting from $\mathrm{NH}_{2}$ vibrations of ligands $\left(\mathbf{L}^{\mathbf{1}}\right)$ $\left(\mathrm{L}^{3}\right)$ remained unchanged in all the complexes showing their no involvement in the coordination. The following evidences further support the mode of chelation.

(i) Appearance of the new bands in their metal complexes at $520-539$ and $441-465 \mathrm{~cm}^{-1}$ which were assigned to $v(\mathrm{M}-\mathrm{N})[20]$ and $v(\mathrm{M}-\mathrm{O})$ vibrations, respectively, and these bands were absent in their uncomplexed ligands.

(ii) The $(\mathrm{C}-\mathrm{O})$ vibrations of ligand $\left(\mathrm{L}^{1}\right)$ at $1090 \mathrm{~cm}^{-1}$ were shifted to lower frequency $1072-1077 \mathrm{~cm}^{-1}$ in the metal(II) complexes (1)-(4). This, in turn, supported the evidence of the participation of heteroatom-O in the coordination.

(iii) Appearance of the new bands at $1377-1383 \mathrm{~cm}^{-1}$ due to $v(\mathrm{C}-\mathrm{O})$ vibrations in the metal(II) complexes (5)(8) indicated the coordination of $\mathrm{OCH}_{3}$ group with the metal atoms [21].

(iv) The disappearance of $v(\mathrm{OH})$ band at $3385 \mathrm{~cm}^{-1}$ in (8)-(12) complexes and appearance of new bands at $1375-1381 \mathrm{~cm}^{-1}$ due to the $v(\mathrm{C}-\mathrm{O})$ stretching mode in the complexes revealed the deprotonation of the hydroxyl $\mathrm{OH}$ group found in the ligand $\left(\mathrm{L}^{3}\right)$. It, in turn, indicated that the proton of the $\mathrm{OH}$ group was replaced by the metal ions in the formation of complexes.

(v) All the metal(II) complexes displayed new broad peaks at $3465-3480 \mathrm{~cm}^{-1}$ which were assigned to water molecules.

These new bands were only observed in the spectra of the complexes but absent in the spectra of the Schiff bases. Therefore, these clues supported the evidence of the participation of heteroatom- $\mathrm{O}$, deprotonation of benzilidene-O, and azomethine- $\mathrm{N}$ in the coordination. All these evidences compromise with the complexation of the metal(II) ions to the prepared Schiff bases.
3.2. ${ }^{1} \mathrm{H}$ NMR Spectra. ${ }^{1} \mathrm{H}$ NMR spectra of the Schiff bases and their diamagnetic $\mathrm{Zn}$ (II) complexes were recorded in DMSO- $\mathrm{d}_{6} \cdot{ }^{1} \mathrm{H}$ NMR spectral data of the Schiff bases $\left(\mathbf{L}^{\mathbf{1}}\right)-$ $\left(\mathbf{L}^{3}\right)$ and their diamagnetic $\mathrm{Zn}(\mathrm{II})$ complexes are provided in the experimental section. The ${ }^{1} \mathrm{H}$ NMR spectra of the Schiff base ligands $\left(\mathbf{L}^{\mathbf{1}}\right)-\left(\mathbf{L}^{3}\right)$ demonstrated characteristic amino $\left(\mathrm{NH}_{2}\right)$ and azomethine $(\mathrm{CH}=\mathrm{N})$ protons at $4.85-4.89$ and $7.18-8.85 \mathrm{ppm}$ as a singlet, respectively. The $\left(\mathrm{CH}_{3}\right)$ protons of the ligands $\left(\mathbf{L}^{1}\right)$ were observed at $2.35 \mathrm{ppm}$ as a singlet. The $\left(\mathrm{OCH}_{3}\right)$ proton present in the ligand $\left(\mathrm{L}^{2}\right)$ was observed at $2.95 \mathrm{ppm}$ as a singlet. The $\left(\mathrm{CH}_{2}\right)$ protons present in all the ligands $\left(\mathbf{L}^{1}\right)-\left(\mathbf{L}^{3}\right)$ were observed at $3.05-3.98 \mathrm{ppm}$ as a singlet. In case of the ligand $\left(\mathrm{L}^{3}\right)$ the $\mathrm{O}-\mathbf{H}$ proton was observed at $9.97 \mathrm{ppm}$ as a singlet. The furan protons of ligand $\left(\mathbf{L}^{\mathbf{l}}\right)$ were found at $6.34-6.68 \mathrm{ppm}$ as a doublet. The phenyl protons found in ligands $\left(\mathbf{L}^{2}\right)$ and $\left(\mathrm{L}^{3}\right)$ were found at $6.87-7.75 \mathrm{ppm}$ as a doublet, double doublet, and triplet.

The coordination of the azomethine $(\mathrm{HC}=\mathrm{N})$ nitrogen was assigned by the downfield shifting of the azomethine proton signal from $7.18-8.85$ in fee ligands to $8.78-8.88 \mathrm{ppm}$ in their Zn(II) complexes, respectively. This downfield shifting of azomethine proton in $\mathrm{Zn}$ (II) complexes was attributed to the discharging of electronic cloud towards the $\mathrm{Zn}$ (II) ion. The hydroxyl $(\mathrm{OH})$ proton at $9.97 \mathrm{ppm}$ in the ligand $\left(\mathbf{L}^{3}\right)$ disappeared in the spectra of its $\mathrm{Zn}(\mathrm{II})$ complexes, indicating deprotonation and coordination of the oxygen with the metal ion. All other protons underwent downfield shift by $0.7-0.30 \mathrm{ppm}$ owing to the increased conjugation on complexation with the zinc metal atom. Thus, the number of protons calculated from the integration curves $[22,23]$ and obtained values of the expected $\mathrm{CHN}$ analysis agreed well with each other.

3.3. ${ }^{13} \mathrm{C}$ NMR Spectra. ${ }^{13} \mathrm{C}$ NMR spectra of the Schiff bases and their diamagnetic $\mathrm{Zn}$ (II) complexes were recorded in DMSO- $\mathrm{d}_{6}$. The ${ }^{13} \mathrm{C}$ NMR spectral data are reported along with their possible assignments in the Experimental section and all the carbons were found in the expected regions. The ${ }^{13}$ CNMR spectra of the Schiff base ligands $\left(L^{1}\right)-\left(L^{3}\right)$ showed characteristic azomethine $(\mathrm{CH}=\mathrm{N})$ carbons at 161.7$163.9 \mathrm{ppm}$. The $\left(\mathrm{CH}_{3}\right),\left(\mathrm{CH}_{2}\right)$, and $\left(\mathrm{OCH}_{3}\right)$ carbons of the ligands were observed at $13.5,43.0-55.8$, and $56.3 \mathrm{ppm}$, respectively. All the furanyl and phenyl carbons were found at $107.2-160.5 \mathrm{ppm}$.

Downfield shifting of the azomethine carbons from $\delta$ $161.7-163.9 \mathrm{ppm}$ in the free ligands to $162.9-163.8 \mathrm{ppm}$ in its $\mathrm{Zn}$ (II) complexes was due to shifting of electronic density towards the $\mathrm{Zn}$ (II) ion. Similarly, all carbons of heteroaromatic and phenyl rings being near to the coordination sites also showed downfield shifting by $0.10-0.60 \mathrm{ppm}$ due to the increased conjugation and coordination with the metal atoms. The downfield shifting also confirmed the coordination of the azomethine to the zinc metal atom. Moreover, the presence of the number of carbons is well in agreement with the expected values [24, 25]. Furthermore, the conclusions drawn from these studies present further support to the modes of bonding discussed in their IR and ${ }^{1} \mathrm{H}$ NMR spectra. 
3.4. Mass Spectra. The mass fragmentation pattern of the ligands $\left(\mathbf{L}^{1}\right)-\left(\mathbf{L}^{3}\right)$ followed the cleavage of $\mathrm{C}=\mathrm{N}$ (exocyclic), $\mathrm{C}=\mathrm{C}$, and $\mathrm{C}-\mathrm{O}$ bonds. The mass spectral data and the most stable fragmentation values of the ligands were depicted in Experimental section. All the ligands showed pronounced molecular ion peaks. The data of the Schiff bases shown by mass spectra strongly confirmed the formation of the ligands possessing proposed structures and also their bonding pattern.

3.5. Molar Conductances. Molar conductance studies of the complexes were carried out in DMF. The data of molar conductances $\left(93.5-98.7 \mathrm{ohm}^{-1} \mathrm{~cm}^{2} \mathrm{~mol}^{-1}\right.$ ) of metal(II) complexes (1)-(8) showed that these complexes were electrolytic [26] in nature. The metal(II) complexes (9)-(12) exhibited conductances in the range 13.1-15.9, thus indicating their nonelectrolytic $[27,28]$ nature.

3.6. Magnetic Measurements. The magnetic moment (B.M) values of all the metal(II) complexes, (1)-(12), were obtained at room temperature. The observed magnetic moment values of $\mathrm{Co}$ (II) complexes were found in the range of 4.32-4.68 B.M indicating the $\mathrm{Co}(\mathrm{II})$ complexes as highspin suggesting three unpaired electrons in an octahedral environment [29]. The Ni(II) complexes showed magnetic moment values in the range of 3.39-3.55 B.M indicative of two unpaired electrons per $\mathrm{Ni}(\mathrm{II})$ ion suggesting these complexes to have an octahedral [30] geometry. The measured magnetic moment values 1.93-1.97 B.M for $\mathrm{Cu}(\mathrm{II})$ complexes are indicative of one unpaired electron per $\mathrm{Cu}(\mathrm{II})$ ion for $\mathrm{d}^{9}$-system suggesting octahedral [31] geometry. All the $\mathrm{Zn}$ (II) complexes were found to be diamagnetic [32] as expected.

3.7. Electronic Spectra. The electronic spectra of Co(II) complexes generally exhibited [33] three absorption bands in the regions 8515-8690, 17511-17967, and $29542-29982 \mathrm{~cm}^{-1}$ which may be assigned to $4 \mathrm{~T}_{1} \mathrm{~g} \rightarrow 4 \mathrm{~T}_{2} \mathrm{~g}(\mathrm{~F}), 4 \mathrm{~T}_{1} \mathrm{~g} \rightarrow 4 \mathrm{~A}_{2} \mathrm{~g}(\mathrm{~F})$, and $4 \mathrm{~T}_{1} \mathrm{~g} \rightarrow 4 \mathrm{Tg}(\mathrm{P})$ transitions, respectively, and are suggestive of octahedral geometry around the $\mathrm{Co}(\mathrm{II})$ ion. The electronic spectral data of $\mathrm{Ni}$ (II) complexes showed [34] the bands in the regions 8599-8762, 17620-17850, and 25661$25890 \mathrm{~cm}^{-1}$ assigned, respectively, to the $\mathrm{d}-\mathrm{d}$ transitions of $3 \mathrm{~A}_{2} \mathrm{~g}(\mathrm{~F}) \rightarrow 3 \mathrm{~T}_{2} \mathrm{~g}(\mathrm{~F})$ and $3 \mathrm{~A}_{2} \mathrm{~g}(\mathrm{~F}) \rightarrow 3 \mathrm{~T}_{1} \mathrm{~g}(\mathrm{~F})$. Also a strong band due to metal to ligand charge transfer appeared at $29675-29895 \mathrm{~cm}^{-1}$. The electronic spectra of all the $\mathrm{Cu}(\mathrm{II})$ complexes exhibited [35] absorption bands in the region at $8515-8737$ and $17215-17672 \mathrm{~cm}^{-1}$ which may be assigned to the transitions $2 \mathrm{Eg} \rightarrow 2 \mathrm{~T}_{2} \mathrm{~g}$. The high energy band at $29528-29982 \mathrm{~cm}^{-1}$ was due to forbidden ligand to metal charge transfer. On the basis of electronic spectra, octahedral geometry around the $\mathrm{Cu}(\mathrm{II})$ ion was suggested. The $\mathrm{Zn}(\mathrm{II})$ complexes did not show any d-d transition thus showing diamagnetic nature and their spectra were dominated only by a charge transfer band [36] at $28382-28653 \mathrm{~cm}^{-1}$.

\subsection{Biological Evaluation}

3.8.1. Antibacterial Bioassay (In Vitro). The newly synthesized Schiff bases $\left(\mathbf{L}^{\mathbf{1}}\right)-\left(\mathbf{L}^{3}\right)$ and their metal(II) complexes (1)-(12) have been subjected for the screening of their in vitro antibacterial activity against Escherichia coli, Streptococcus faecalis, Pseudomonas aeruginosa, Klebsiella pneumoniae, Staphylococcus aureus, and Bacillus subtilis bacterial strains according to standard procedure [11] and results were reported in Table 1. The obtained results were compared with those of the standard drug streptomycin. The synthesized ligand $\left(\mathbf{L}^{1}\right)$ exhibited a significant $(16-18 \mathrm{~mm})$ activity against Streptococcus faecalis, Pseudomonas aeruginosa, Klebsiella pneumoniae, and Bacillus subtilis bacterial strains and moderate (13-14 $\mathrm{mm}$ ) activity against Escherichia coli and Staphylococcus aureus. The ligand $\left(\mathbf{L}^{2}\right)$ showed a significant $(17-18 \mathrm{~mm})$ activity against Pseudomonas aeruginosa and Staphylococcus aureus, moderate (13-14 mm) activity against Escherichia coli, Streptococcus faecalis, and Bacillus subtilis, and weaker $(10 \mathrm{~mm})$ against Klebsiella pneumoniae. The ligand $\left(\mathrm{L}^{3}\right)$ demonstrated a significant $(16-19 \mathrm{~mm})$ activity against Escherichia coli and Streptococcus faecalis, moderate (11-15 mm) against Pseudomonas aeruginosa, Klebsiella pneumoniae, and Bacillus subtilis, and weaker $(09 \mathrm{~mm})$ activity by Staphylococcus aureus. The metal complexes (4), (5), and (8)(10) displayed overall significant $(\geq 16 \mathrm{~mm})$ activity against all the bacterial strains. Compounds (1)-(3) exhibited overall a significant $(16-20 \mathrm{~mm})$ activity against all bacterial strains except Streptococcus faecalis and Staphylococcus aureus of (1), Escherichia coli and Klebsiella pneumoniae of (2), and Staphylococcus aureus of (3) which possessed moderate (12$15 \mathrm{~mm}$ ) activity. Beside this, the compounds (6), (7), and (9) exhibited overall a significant (16-24 mm) activity against all bacterial strains except Streptococcus faecalis of (6) and Streptococcus faecalis and Klebsiella pneumoniae of (7) which possessed moderate (14-15 mm) activity. Also, compound (11) showed significant $(15-22 \mathrm{~mm})$ activity against Escherichia coli, Streptococcus faecalis, Pseudomonas aeruginosa, Klebsiella pneumoniae, and Staphylococcus aureus, and moderate $(13 \mathrm{~mm})$ activity was shown against Klebsiella pneumoniae. Compound (12) exhibited significant (15-21 mm) activity against Escherichia coli, Streptococcus faecalis, Klebsiella pneumoniae, Staphylococcus aureus, and Bacillus subtilis, except Pseudomonas aeruginosa which possessed moderate (11$14 \mathrm{~mm}$ ) activity.

3.8.2. Antifungal Bioassay (In Vitro). The antifungal screening of all compounds was carried out against Trichophyton mentogrophytes, Epidermophyton floccosum, Aspergillus niger, Microsporum canis, Fusarium culmorum, and Trichophyton schoenleinii fungal strains (Table 2) according to the literature protocol [12]. The results of inhibition were compared with the results of standard drugs, miconazole and amphotericin B. The ligand $\left(\mathbf{L}^{1}\right)$ possessed significant $(57 \%)$ activity against Epidermophyton floccosum fungal strain, moderate (37-49\%) against Trichophyton mentogrophytes, Microsporum canis, Fusarium culmorum, and Trichophyton schoenleinii, but no activity against Aspergillus niger. The ligand $\left(\mathbf{L}^{2}\right)$ 
TABLE 3: Minimum inhibitory concentration $(\mu \mathrm{g} / \mathrm{mL})$ of the selected compounds (3)-(5) and (9)-(12) against selected bacteria.

\begin{tabular}{|c|c|c|c|c|c|c|}
\hline Number & E. coli & S. faecalis & P. aeruginosa & K. pneumoniae & S. aureus & B. subtilis \\
\hline (3) & - & 52.64 & - & - & - & - \\
\hline (4) & 45.68 & - & - & - & - & - \\
\hline (5) & 52.17 & 33.16 & 35.34 & - & - & - \\
\hline (9) & - & - & - & 51.22 & - & - \\
\hline (10) & 38.34 & 47.21 & 44.41 & 33.67 & - & - \\
\hline (11) & - & - & - & - & - & 49.26 \\
\hline (12) & 53.41 & 35.67 & 43.94 & 32.11 & 40.33 & 47.82 \\
\hline
\end{tabular}

showed significant (55-58\%) activity against Trichophyton mentogrophytes and Fusarium culmorum and moderate (3950\%) activity against Epidermophyton floccosum, Aspergillus niger, and Trichophyton schoenleinii, and it was inactive against Microsporum canis. However, $\left(\mathrm{L}^{3}\right)$ exhibited significant (55-60\%) activity against Fusarium culmorum and Aspergillus niger but showed moderate (38-49\%) activity against Trichophyton mentogrophytes, Epidermophyton floccosum, Microsporum canis, and Trichophyton schoenleinii. The compound (1) showed significant (55-65\%) activity against all fungal strains except Aspergillus niger strain which had weaker (18\%) activity. Similarly, compound (2) also possessed significant (55-71\%) activity against Trichophyton mentogrophytes, Epidermophyton floccosum, Aspergillus niger, and Fusarium culmorum and moderate (41\%) activity against Trichophyton schoenleinii but weaker (11\%) activity against Microsporum canis. As well, the compound (3) displayed significant (60-68\%) activity against Epidermophyton floccosum and Aspergillus niger, moderate (43-49\%) against Trichophyton mentogrophytes, Microsporum canis, and Fusarium culmorum, and also weaker (15\%) activity against Trichophyton schoenleinii. The compounds (4) and (5) similarly possessed significant (55-74\%) activity against all fungal strains except Aspergillus niger strain of compound (4) which observed moderate (39\%) activity. The compound (6) exhibited significant (55-72\%) activity against Trichophyton mentogrophytes, Aspergillus niger, Microsporum canis, and Fusarium culmorum fungal strains, but strain Trichophyton schoenleinii showed moderate (42\%) activity and was inactive against Epidermophyton floccosum. Besides this, the compound (7) demonstrated significant (56-75\%) activity against all strains except Microsporum canis which had weaker (28\%) activity. The compound (8) showed significant (56-70\%) activity against Trichophyton mentogrophytes, Epidermophyton floccosum, Microsporum canis, and Trichophyton schoenleinii, and also moderate (35-42\%) activity was observed against Aspergillus niger and Fusarium culmorum, respectively. The compound (9) showed significant (5569\%) activity against Trichophyton mentogrophytes, Microsporum canis, Aspergillus niger, and Fusarium culmorum and moderate (38\%) activity against Epidermophyton floccosum and it was inactive against Trichophyton schoenleinii. On the contrary, the compound (10) exhibited significant (61$78 \%)$ activity against all fungal strains. The compound (11) presented significant (55-67\%) activity against Trichophyton mentogrophytes, Epidermophyton floccosum, and
Fusarium culmorum fungal strains, and other left behind strains Aspergillus niger, Microsporum canis, and Trichophyton schoenleinii showed moderate (36-40\%) activity. Similarly, the compound (12) showed significant activity (5570\%) against Epidermophyton floccosum, Microsporum canis, and Trichophyton schoenleinii although left behind strains Trichophyton mentogrophytes, Aspergillus niger, and Fusarium culmorum displayed moderate (34-49\%) activity. It is obvious from the data reported in Table 2 that $\left(\mathrm{L}^{3}\right)$ showed overall good fungal activity as compared to other two ligands. The $\mathrm{Ni}$ (II) complex (10) of $\left(\mathrm{L}^{3}\right)$ was found to be the most active complex. The metal(II) complexes showed enhanced activity results rather than their uncomplexed Schiff bases due to complexation.

3.8.3. Minimum Inhibitory Concentration (MIC). The synthesized ligands and their transition metal(II) complexes showing promising antibacterial activity (above 80\%) were selected for MIC studies and obtained results are reported in Table 3. The antibacterial results indicated that all the metal(II) complexes (3)-(5) and (9)-(12) were found to display activity more than $80 \%$; therefore, these complexes were selected for their MIC screening. The MIC values of these compounds fall in the range 32.11 to $53.41 \mu \mathrm{g} / \mathrm{mL}$. Amongst these, the compound (12) was found to be the most active possessing maximum inhibition $32.11 \mu \mathrm{g} / \mathrm{mL}$ against bacterial strain K. pneumoniae.

\section{Conclusions}

Three bidentate N, O donor type Schiff bases were prepared by using ethylene-1,2-diamine with 5-methyl-2-furaldehyde, 2-anisaldehyde, and 2-hydroxybenzaldehyde in an equimolar ratio. These ligands were further complexed with transition metals to produce their new metal complexes. Elemental analysis and spectral data of the uncomplexed ligands and their metal(II) complexes were found to be in good agreement with their structures, indicating high purity of all the compounds. All ligands and their metal complexes were screened for antimicrobial activity. The results of antimicrobial activity indicated that metal complexes have significantly higher activity than corresponding ligands. This higher activity might be due to chelation process which reduces the polarity of metal ion by coordinating with ligands. 


\section{Conflict of Interests}

The authors declare that there is no conflict of interests regarding the publication of this paper and are responsible for the contents and writing of the paper.

\section{Acknowledgments}

The authors are thankful to HEJ Research Institute of Chemistry, International Center for Chemical and Biological Sciences, University of Karachi, Pakistan, for providing their help in taking NMR and mass spectra and, for the help in carrying out antibacterial and antifungal bioassay.

\section{References}

[1] V. Ambike, S. Adsule, F. Ahmed et al., "Copper conjugates of nimesulide Schiff bases targeting VEGF, COX and Bcl-2 in pancreatic cancer cells," Journal of Inorganic Biochemistry, vol. 101, no. 10, pp. 1517-1524, 2007.

[2] N. H. Patel, H. M. Parekh, and M. N. Patel, "Synthesis, characterization and biological evaluation of manganese(II), cobalt(II), nickel(II), copper(II), and cadmium(II) complexes with monobasic (NO) and neutral (NN) Schiff bases," Transition Metal Chemistry, vol. 30, no. 1, pp. 13-17, 2005.

[3] Y. J. Thakor, S. G. Patel, and K. N. Patel, "Synthesis, characterization and biocidal studies of some transition metal complexes containing tetra dentate and neutral bi dentate schiff base," Journal of Chemical and Pharmaceutical Research, vol. 2, no. 5, pp. 518-525, 2010.

[4] R. Ramesh, P. K. Suganthy, and K. Natarajan, "Synthesis, spectra and electrochemistry of $\mathrm{Ru}(\mathrm{III})$ complexes with tetradentate schiff bases," Synthesis and Reactivity in Inorganic and MetalOrganic Chemistry, vol. 26, no. 1, pp. 47-60, 1996.

[5] M. M. Abd-Elzaher, "Spectroscopic characterization of some tetradentate schiff bases and their complexes with nickel, copper and zinc," Journal of the Chinese Chemical Society, vol. 48, no. 2, pp. 153-158, 2001.

[6] A. A. Jarrahpour, M. Motamedifar, K. Pakshir, N. Hadi, and M. Zarei, "Synthesis of novel azo Schiff bases and their antibacterial and antifungal activities," Molecules, vol. 9, no. 10, pp. 815-824, 2004.

[7] P. Nagababu, J. N. Latha, P. Pallavi, S. Harish, and S. Satyanaravana, "Studies on antimicrobial activity of cobalt(III) ethylenediamine complexes," Canadian Journal of Microbiology, vol. 52, no. 12, pp. 1247-1254, 2006.

[8] K. Sasikala and S. Arunachalam, "Antimicrobial activity, spectral studies and micellar properties of some surfactantcobalt(III) complexes," Chemical Science Transactions, vol. 2, supplement 1, pp. S157-S166, 2013.

[9] J. M. Lazić, L. Vučićević, S. Grgurić-Šipka et al., "Synthesis and in vitro anticancer activity of octahedral platinum(IV) complexes with cyclohexyl-functionalized ethylenediamineN,NI-diacetate- type ligands," ChemMedChem, vol. 5, no. 6, pp. 881-889, 2010.

[10] M. H. K. Mostafa, H. I. Eman, G. M. Gehad, M. Z. Ehab, and B. Ahmed, "Synthesis and characterization of a novel schiff base metal complexes and their application in determination of iron in different types of natural water," Open Journal of Inorganic Chemistry, vol. 2, no. 2, pp. 13-21, 2012.
[11] A. U. Rahman, M. I. Choudhary, and W. J. Thomsen, Bioassay Techniques for Drug Development, Harwood Academic Publishers, Amsterdam, The Netherlands, 2001.

[12] A. U. Rahman, M. I. Choudhary, and W. J. Thomsen, Bioassay Techniques for Drug Development, Harwood Academic, Amsterdam, The Netherlands, 2001.

[13] J. L. McLaughlin, C.-J. Chang, and D. L. Smith, “"Bench Top” bioassays for the discovery of bioactive natural products: an update, structure and chemistry (part-B)," in Studies in Natural Products Chemistry, Atta-ur-Rahman, Ed., vol. 9, p. 383, Elsevier Science, Amsterdam, The Netherlands, 1991.

[14] B. S. Holla, M. Mahalinga, M. S. Karthikeyan, B. Poojary, P. M. Akberali, and N. S. Kumari, "Synthesis, characterization and antimicrobial activity of some substituted 1,2,3-triazoles," European Journal of Medicinal Chemistry, vol. 40, no. 11, pp. 1173-1178, 2005.

[15] P. Noblía, M. Vieites, B. S. Parajón-Costa et al., "Vanadium(V) complexes with salicylaldehyde semicarbazone derivatives bearing in vitro anti-tumor activity toward kidney tumor cells (TK-10): crystal structure of $\left[\mathrm{V}^{V} \mathrm{O}_{2}\right.$ (5-bromosalicylaldehyde semicarbazone)]," Journal of Inorganic Biochemistry, vol. 99, no. 2, pp. 443-451, 2005.

[16] G. B. Bagihalli, P. S. Badami, and S. A. Patil, "Synthesis, spectral characterization and in vitro biological studies of $\mathrm{Co}(\mathrm{II}), \mathrm{Ni}$ (II) and $\mathrm{Cu}$ (II) complexes with 1,2,4-triazole Schiff bases," Journal of Enzyme Inhibition and Medicinal Chemistry, vol. 24, no. 2, pp. 381-394, 2009.

[17] Y. Prashanthi and S. Raj, "Synthesis and characterization of transition metal complexes with $\mathrm{N}, \mathrm{O} ; \mathrm{N}, \mathrm{N}$ and $\mathrm{S}, \mathrm{N}$-donor Schifff base ligands," Journal of Scientific Research, vol. 2, no. 1, pp. 114-126, 2010.

[18] A. D. Shinde, B. Y. Kale, B. B. Shingate, and M. S. Shingare, "Synthesis and characterization of 1-benzofuran-2-yl thiadiazoles, triazoles and oxadiazoles by conventional and nonconventional methods," Journal of the Korean Chemical Society, vol. 54, no. 5, pp. 582-588, 2010.

[19] S. H. Sumrra and Z. H. Chohan, "Metal based new triazoles: their synthesis, characterization and antibacterial/antifungal activities," Spectrochimica Acta A: Molecular and Biomolecular Spectroscopy, vol. 98, pp. 53-61, 2012.

[20] M. Hanif and Z. H. Chohan, "Design, spectral characterization and biological studies of transition metal(II) complexes with triazole Schiff bases," Spectrochimica Acta A: Molecular and Biomolecular Spectroscopy, vol. 104, pp. 468-476, 2013.

[21] Z. H. Chohan and S. H. Sumrra, "Synthesis, characterization and biological studies of oxovanadium (IV) complexes with triazole-derived Schiff bases," Applied Organometallic Chemistry, vol. 24, no. 2, pp. 122-130, 2010.

[22] R. A. Nyquist, Interpreting Infrared, Raman and Nuclear Magnetic Resonance Spectra, vol. 2, Academic Press, New York, NY, USA, 2001.

[23] H. Gunther, NMR Spectroscopy: Basic Principles, Concepts, and Applications in Chemistry, John Wiley \& Sons, 2nd edition, 1995.

[24] R. A. Freeman, Handbook of Nuclear Magnetic Resonance, Longman, Essex, UK, 2nd edition, 1997.

[25] M. Levitt, Spin Dynamics: Basics of Nuclear Magnetic Resonance, John Wiley \& Sons, 2001.

[26] W. J. Geary, “The use of conductivity measurements in organic solvents for the characterisation of coordination compounds," Coordination Chemistry Reviews, vol. 7, no. 1, pp. 81-122, 1971. 
[27] I. S. Raja, M. Christudhas, and G. A. G. Raj, "Synthesis, characterization, metal ion intake and antibacterial activity of cardanol based polymeric Schiff base transition metal complexes using Ethylenediamine," Journal of Chemical and Pharmaceutical Research, vol. 3, no. 6, pp. 127-135, 2011.

[28] J. Liu, B. Wu, B. Zhang, and Y. Liu, "Synthesis and characterization of metal complexes of $\mathrm{Cu}(\mathrm{II}), \mathrm{Ni}(\mathrm{II}), \mathrm{Zn}(\mathrm{II}), \mathrm{Co}(\mathrm{II}), \mathrm{Mn}(\mathrm{II})$ and Cd(II) with tetradentate schiff bases," Turkish Journal of Chemistry, vol. 30, no. 1, pp. 41-48, 2006.

[29] S. Sarkar and K. Dey, "Synthesis and spectroscopic characterization of some transition metal complexes of a new hexadentate $\mathrm{N}_{2} \mathrm{~S}_{2} \mathrm{O}_{2}$ Schiff base ligand," Spectrochimica Acta A: Molecular and Biomolecular Spectroscopy, vol. 62, no. 1-3, pp. 383-393, 2005.

[30] K. Serbest, H. Kayi, M. Er, K. Sancak, and I. Deǧirmencioğlu, "Ni(II), Cu(II), and $\mathrm{Zn}(\mathrm{II})$ complexes of tetradentate schiff base containing two thiadiazoles units: Structural, spectroscopic, magnetic properties, and molecular modeling studies," Heteroatom Chemistry, vol. 19, no. 7, pp. 700-712, 2008.

[31] R. M. El-Shazly, G. A. A. Al-Hazmi, S. E. Ghazy, M. S. ElShahawi, and A. A. El-Asmy, "Spectroscopic, thermal and electrochemical studies on some nickel(II) thiosemicarbazone complexes," Spectrochimica Acta A: Molecular and Biomolecular Spectroscopy, vol. 61, no. 1-2, pp. 243-252, 2005.

[32] S. Chandra and L. K. Gupta, "EPR, mass, IR, electronic, and magnetic studies on copper (II) complexes of semicarbazones and thiosemicarbazones," Spectrochimica Acta A, vol. 61, no. 12, pp. 269-275, 2005.

[33] Z. H. Chohan and H. A. Shad, "Metal-based new sulfonamides: design, synthesis, antibacterial, antifungal, and cytotoxic properties," Journal of Enzyme Inhibition and Medicinal Chemistry, vol. 27, no. 3, pp. 403-412, 2012.

[34] H. Temel, Ü. Çakir, B. Otludil, and H. I. Uğraş, "Synthesis, spectral and biological studies of $\mathrm{Mn}(\mathrm{II}), \mathrm{Ni}(\mathrm{II}), \mathrm{Cu}(\mathrm{II})$, and $\mathrm{Zn}$ (II) complexes with a tetradentate Schiff base ligand. Complexation studies and the determination of stability constants (Ke)," Synthesis and Reactivity in Inorganic and Metal-Organic Chemistry, vol. 31, no. 8, pp. 1323-1337, 2001.

[35] D. L. Pavia, G. M. Lampman, G. S. Kriz, and J. R. Vyvyan, Spectroscopy, Brooks/Cole, Florence, Ky, USA, 2007.

[36] W. E. Estes, D. P. Gavel, W. E. Hatfield, and D. J. Hodgson, "Magnetic and structural characterization of dibromo- and dichlorobis(thiazole)copper(II)," Inorganic Chemistry, vol. 17, no. 6, pp. 1415-1421, 1978. 

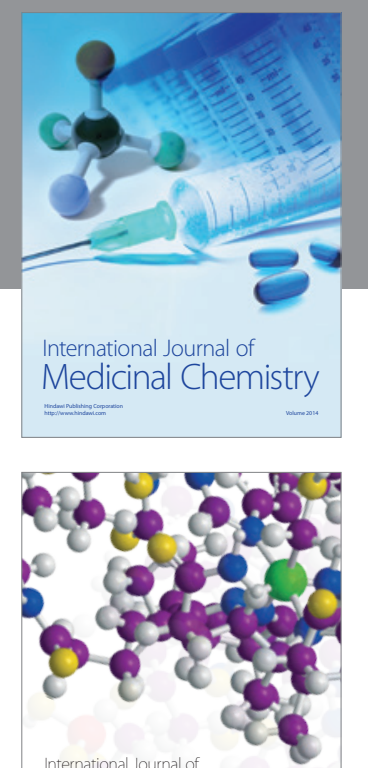

\section{Carbohydrate} Chemistry

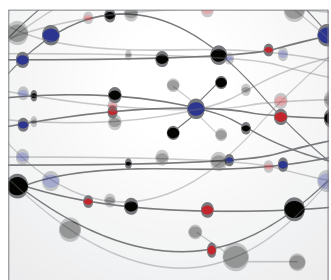

The Scientific World Journal
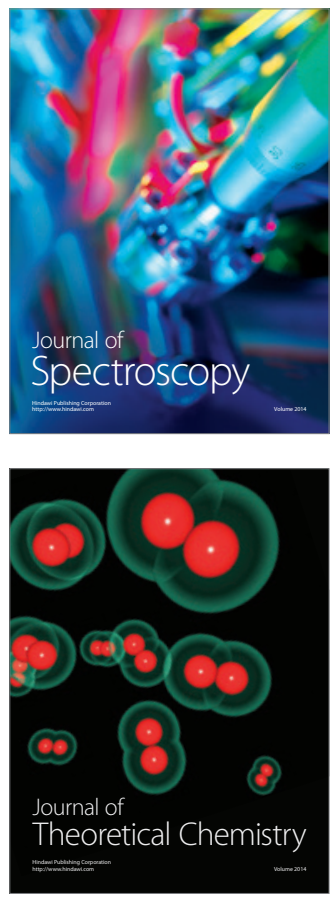
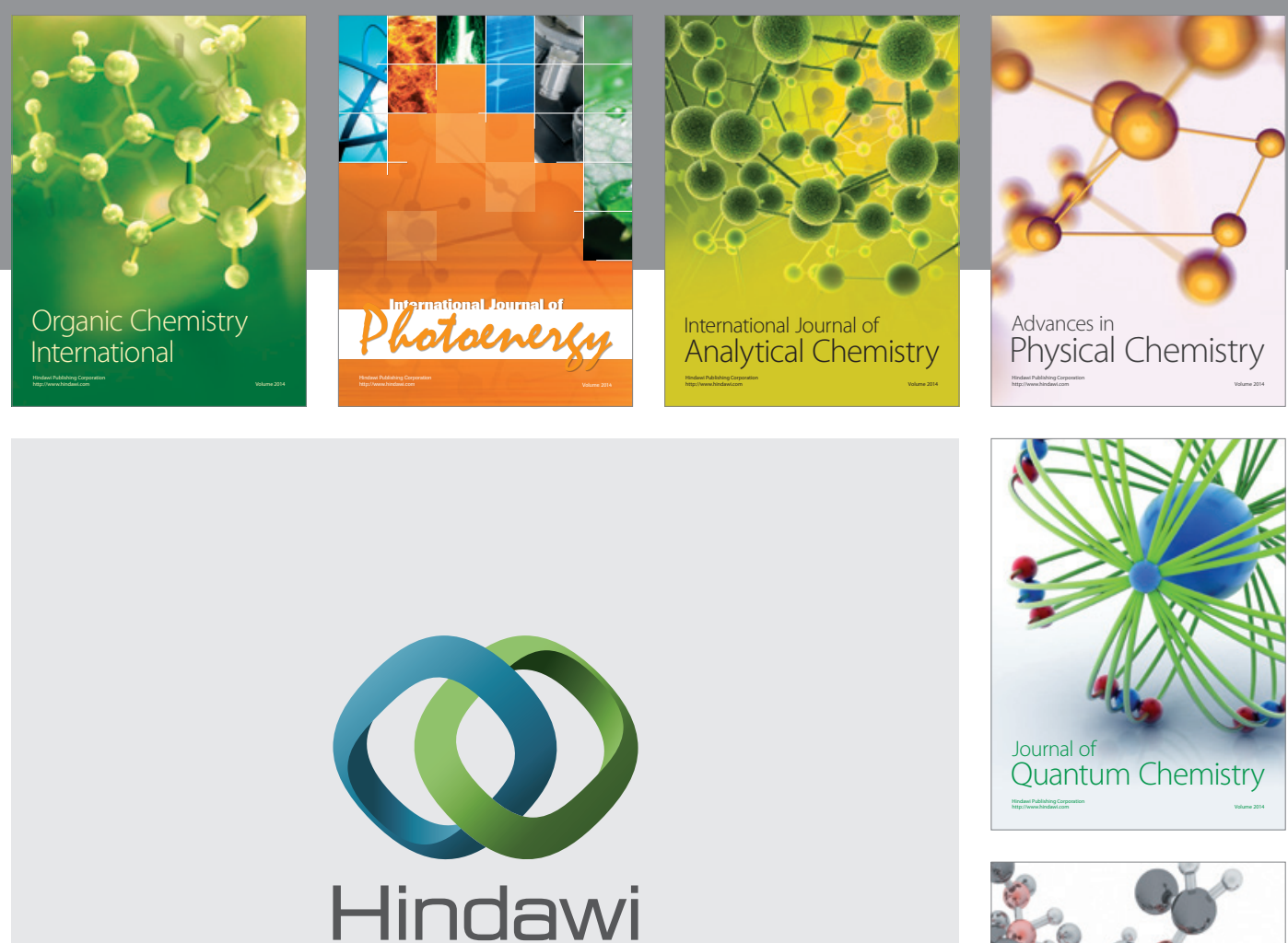

Submit your manuscripts at

http://www.hindawi.com

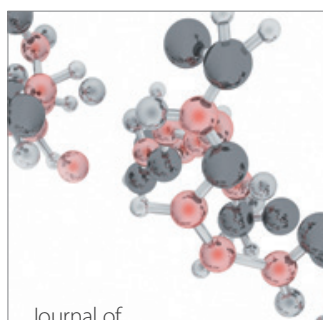

Analytical Methods

in Chemistry

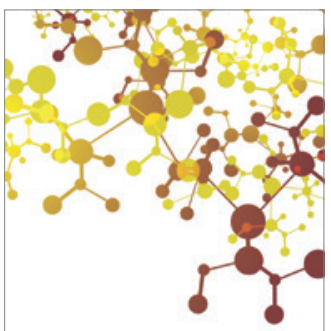

Journal of

Applied Chemistry

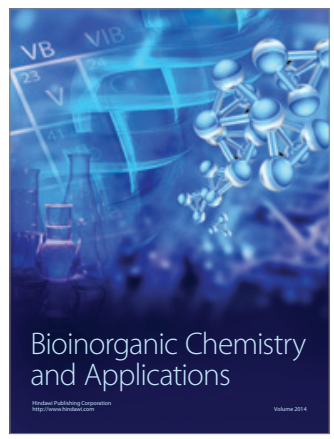

Inorganic Chemistry
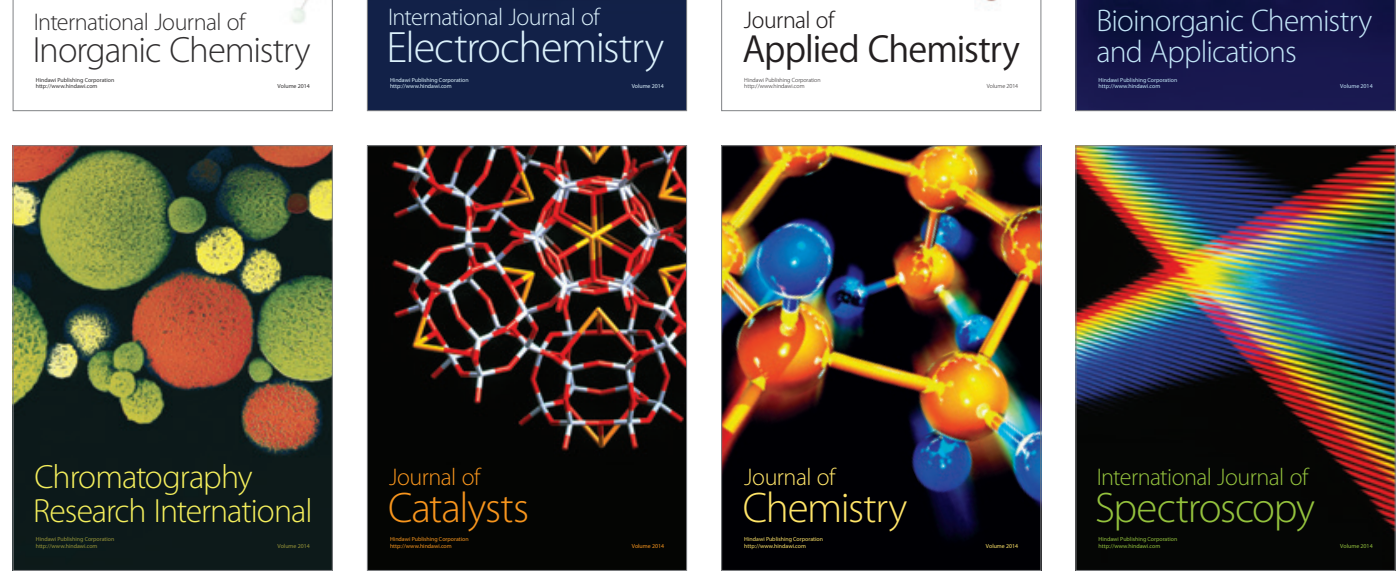